\title{
Do Hope Foster Innovative Work Behavior through Employee Engagement and Knowledge Sharing Behavior? A Conservation of Resources Approach Using MPLUS tool
}

\begin{abstract}
Afsheen Fatima ${ }^{1}$, Muhammad Asif Khan ${ }^{2}$
Abstract

The aim of this study is to develop and test a conceptual path model that examines the relationship among positive psychological resources, i.e. hope, positive organizational behaviors (knowledge sharing behavior (KSB) and innovative work behavior (IWB)) and employee engagement (job engagement (JE) and organizational engagement $(\mathrm{OE})$ ). The framework for this study is drawn on the basis of conservation of resource theory using causal research design. This study investigates the impact of hope on employees' innovative work behavior through engagement and knowledge sharing behavior. Therefore, the present study has explored the indirect mechanism of hope and innovative work behavior through sequential mediation of engagement and knowledge sharing behavior that helps in attaining the desired organizational goals as innovative work behavior. Data were collected from 354 respondents in the Information and Communication Technology (ICT) Sector organizations located within twin cities of Pakistan (Islamabad and Rawalpindi) through a self-administered questionnaire. Analysis was conducted using a Structural Equation Modeling (SEM) technique through maximum likelihood estimation using MPlus software. The findings reveals a significant positive impact of hope on IWB through employee engagement and KSB. Limitations and future research recommendations are also discussed at the end of the study.
\end{abstract}

Keywords: Job engagement, organizational engagement, hope, knowledge sharing, innovative work behaviors.

\section{Introduction}

Growth of the ICT industry (including the landlines, the internet, cellular, and

1 PhD Scholar, Shaheed Zulfiqar Ali Bhutto Institute of Science E Technology (SZABIST), Islamabad.Email:afsheen@uaar.edu.pk

2 Professor, Shaheed Zulfiqar Ali Bhutto Institute of Science Ë Technology (SZABIST), Islamabad. Email:dr.asif@szabist-isb.edu.pk

\begin{tabular}{lll} 
ARTICLE HISTORY & & \\
\hline 11 Sep, 2017 Submission Received & 7 Oct, 2017 & First Review \\
\hline 4 Nov, 2017 Revised Version Received & 15 Oct, 2017 & Second Review \\
\hline
\end{tabular}

15 Nov, 2017 Accepted 
software businesses) in the $21^{\text {st }}$ century is facing an increased competition and needs a distinct measurement of their services. Service level and scalability features of this sector are continuously introduced while simultaneously achieving certain levels of service quality and sustainable growth (Tseng, Lin, Lim \& Teehankee, 2015). The main focus of the traditional organizations is on total quality management, cost-competitiveness and customer-focused-services. All these activities continuously require service innovation for a profitable business process. In pushing for a consistent high-performance service, the service innovation and its accompanying dynamic capabilities are the key drivers for the current generation of excellent service practices. In such a competitive IT environment, hiring and retaining talented workers is a key to develop service quality and customer satisfaction. It appears that management of ICT sector organizations needs to hire individuals through rigorous selection techniques whose personality, skills and ability fit the demands of their jobs (Gould-Williams, Mostafa \& Bottomley, 2013).

An individual resource that has gained only slight attention in management research is hope (Peterson \& Byron, 2008). Hope is defined as "a positive motivational state that is based on (a) agency and (b) pathways" (Snyder, Irving \& Anderson, 1991, p. 287). Agency refers to a goal-directed energy and pathways mean planning to meet goals. Both agency and pathways are needed to elevate higher levels of hope (Snyder, 2002). Both dimensions are "functionally inseparable" (Peterson \& Byron, 2008, p. 786).

Hope is an important driver of innovative work behavior, it "requires some level of internal, sustaining force that pushes individuals to persevere in the face of challenges inherent to creative work" (Shalley \& Gilson, 2004, p. 36). IWB is the process of exploring the opportunities and generating new ideas (Luthans, Avolio, Avey \& Norman, 2007). According to Luthans, Youssef and Avolio (2007, p. 74) "hopeful employees tend to be creative and resourceful, even with tight budgets". Yet, to the best of researchers' knowledge, no empirical study has been conducted for examining a path linking hope to IWB. This study sought to deal with this lack of research by examining the path in which hope predicts IWB, through simultaneous mediating roles of engagement and KSB. Though studies have found that hopeful employees are engaged workers (Karatepe, 2014; Ouweneel, Le Blanc, Schaufeli \& Wiihe, 2012), and that engaged workers are potentially knowledge sharer (Chen, Zhang \& Vogel, 2011; Tang, Bavik, Chen \& Tjosvold, 2015), and those who share their knowledge are more innovative (Radaelli, Lettieri, Mura \& Spiller, 2014). To the best of researchers' knowledge, no empirical study has combined five variables together in one framework. In addition, the fact that this empirical research was conducted in Pakistan, an understudy context in the Industrial Psychology (I-O) literature also seems to be positive. 
Scholars have advised to conduct innovation-related research "among organizations in emerging economies, particularly in Asian settings" (Drazin \& Schoonhoven, 1996, p. 1081). Also, Bartram and Rimmer (2012, p. 1) argue "the economic dominance of China and India and their near neighbors has triggered enormous curiosity among HR researchers". Thus, there is a need to test these theories in contexts other than the USA and Europe. This research answers these gaps and attempts to fill the gap in theory of hope and innovation in an Asian context (i.e., Pakistan), and in so doing establishes external validity of research findings obtained from Western contexts, using the framework of Hobfoll (2001) conservation of resources theory.

A synthesis of the current literature delineates several gaps in hope research. First, the extant literature calls to examine the outcomes of hope (Alarcon, Bowling $\&$ Khazon, 2013). Despite its importance, hope and its impact on individual level consequences are ignored (Yavas, Babakus \& Karatepe, 2013). Likewise, not much is known about the impact of hope on job engagement (Ouweneel et al., 2012). More importantly, studies regarding engagement as a process that connects personal characteristics to individual level consequences are limited in existing literature (Rich, LePine \& Crawford, 2010). In their recent study, De Waal and Pienaar (2013) also discuss that what is known about the relationship between the two constructs has remained mostly theoretical.

Second, it has been discussed in a number of studies that there is a need to examine the positive strengths and well-being of employees in organizations (Luthans et al., 2007). Recent meta-analytic studies reveal that there are studies linking psychological resources to satisfaction outcomes (Dawkins, Martin, Scott \& Sanderson, 2013). However, empirical research about personality variables activating IWB in the ICT management literature is yet limited (Abbas \& Raja, 2015). Realizing this gap in existing research, this study examines the impact of hope on job and organizational engagement simultaneously. These two engagement types jointly further affect KSB of employees. And finally, KSB affects critical innovation outcome i.e., IWB.

Third, a careful examination of the management literature particularly ICT sector indicates that research is available that has examined factors influencing the engagement. However, the preponderance of these studies has used only one form of engagement; i.e. job engagement ignoring organizational engagement (e.g. Kim $\&$ Park, 2017). Job engagement is "a positive, fulfilling, work-related state of mind that is characterized by vigor, dedication, and absorption" (Schaufeli, Salanova, Gonzales-Roma, \& Bakker, 2002, p. 74). While, organizational engagement is "the degree of absorption into one's role performance in an organization" (Saks, 2006). Comparatively less researches have examined organizational engagement that predicts employees' outcomes (Juhdi, Pawan, \& Hansaram, 2013). Even less studies are 
available that have simultaneously examined the role of multiple types of engagement (Saks, 2006). More, importantly, to the best of authors' knowledge, no research to date investigated the simultaneous mediating effects of the JE, OE and KSB on the hope-IWB link. Only one study was found to test the direct impact of psychological resources on innovative performance in the telecom sector of Pakistan without considering intervening variables in this complex relation (Abbas \& Raja 2015).

Fourth and most notably, present insight into the effectiveness of personal resources, i.e. hope in enhancing engagement and positive organizational behaviors in novel and under-researched contexts like Pakistan is even rare. The overwhelming majority of empirical studies on hope have been conducted in the United States. This calls for research investigating psychological resources in different cultures (Choi \& Lee, 2014). Thus, it is vital to explore the feasibility of hope as a determinant of individual level outcomes in newer work settings. Finally, this study has tested the model using MPlus software, which allows to test a complicated model and provides specific direct and indirect effects of all the desired relations.

Based on conservation of resources (COR) theory as a theoretical underpinning, the present research develops and examines a conceptual framework that examines how hope is related to IWB through a path of employee engagement and KSB. These links are examined through data gathered from ICT sector employees in Pakistan.

The overarching aim of the present research is to examine the link between hope and IWB. The two main research objectives are:

1. To examine the relationships between hope, job engagement, organizational engagement, KSB and IWB in the Pakistani ICT sector.

2. To test the mediating roles of job engagement, organizational engagement and $\mathrm{KSB}$ on the relationship between hope and IWB.

\section{Literature Review}

\subsection{Theory and hypotheses development}

The COR theory provides guidance regarding the effect of hope on IWB via WE, OE and KSB. Specifically, engagement is developed in response to an abundance of resources. Resources that are personal-dependent tend to create resource caravans. These resource caravans would lead to motivation in terms of engagement. Xanthopoulou, Bakker and Ilies (2012) contend that the availability of a resourceful work environment can initiate employees' positive emotions that relate to personal resources. Elevated levels of positivity will contribute to maintaining a high level of 
individual motivation. Finally, according to the assumptions of positive caravans and gain cycles and spirals present in the COR theory, positive well-being at work, namely, engagement, can accumulate into well-being in other domains, for instance, into knowledge sharing and innovation.

In short, employees who score high in hope will experience energy and dedication and will be happily engrossed in their work and organization. This will further lead to positive behaviors i.e., KSB and IWB.

\subsection{Hope}

In view of Snyder (2002), hope is "a cognitive process, comprised of pathways and agency thinking, through which individuals actively pursue their goals". While path-ways thinking is the ability to find different paths or ways to achieve a goal, agency thinking refers to the positive force required to begin and put up with moving towards one's goals. Snyder introduced the concept of hope theory based on his earlier work focused on how people distance themselves from mistakes and failures. Later, he investigated the reverse concept, or how people move closer to what they do want, such as a direction toward established goals (Rand \& Cheavens, 2009).

Hope is considered as one of the important components of psychological capital. This concept was presented by Luthans and Youssef (2004) as "a way to invest in people for competitive advantage". According to Luthans et al. (2007) "employees who are more hopeful, optimistic, efficacious, and resilient may be more likely to 'weather the storm' of the dynamic global environmental contexts confronting most organizations today better than their counterparts with lower psychological capital" (p. 568).

Norman, Luthans and Luthans (2005) found that hopeful leaders help organizations and its workforce during difficult change. The extant literature also suggests that people having a high degree of hope focus more on success than failure and like to accept the challenges (Snyder, 2002). It has been observed that hope enables individuals to perform better in school, enjoy good health, be brilliant at problem-solving skills, and be psychologically stable (Lopez et al., 2004).

\subsection{Employee engagement}

\subsubsection{Understanding employee engagement}

The concept of employee engagement has become a widespread concept. It is an area of interest for both academicians and practitioners (Robinson, Perryman \& Hayday, 2004). It is the emotional attachment and the willingness to perform the job that leads to positive outcomes (Shuck \& Wollard, 2009). It is described as an 
employee's capability and enthusiasm shown towards an organization. This feeling is sustainable and discretionary in nature (Towers, 2003). It is an inspirational state of mind held by representatives toward the organization and its standards (Robinson et al., 2004). An engaged worker is mindful of the business setting to improve their role in their occupation, for the advantage of the organization.

Employee engagement is portrayed at times only as the "craving for the work" (Truss et al., 2006). Job engagement is defined as "a positive, fulfilling, work-related state of mind that is characterized by vigor, dedication, and absorption" (Schaufeli \& Bakker, 2003). Vigor is characterized by high levels of energy. Dedication refers to being strongly involved in one's work. Absorption is characterized by being fully concentrated at work (Schaufeli \& Bakker, 2003). Moreover, highly engaged individuals are often fully immersed in their work so that time flies (May, Gilson \& Harter, 2004). Organization engagement is an individual attachment and passion about his/ her organization (Saks, 2006). Briefly, engaged workforce has high passion and are eager about their job and organization.

\subsubsection{Distinguishing between job and organizational engagement}

Based on role related engagement, Saks (2006) proposed that employees can have multiple roles within their workplaces, e.g., employees may have work roles (job engagement) and their role being an organizational member (organizational engagement) that together constitute the employee engagement. These were operationalized as an employee's "psychological presence in their job and organization" (Saks, 2006, p. 608). Job engagement is, therefore, one lens through which employees perceive their experiences in the workplace, and other perspectives of engagement might be important (Guest, 2014). To date, it is noted, most of the attention within employee engagement academic research has focused on the job role only (Guest, 2014; Schaufeli et al., 2002). For this research, researchers discover how employee characteristics affect their commitment to and attachment with their job role as well as their role as an organizational member. The researchers' main interest is the association one experiences with something relatively more distant from their selves (organization) as well as something more in their direct control (job) using a multi-foci perspective. Which means realizing that individuals might simultaneously be engaged to differing levels with different targets, e.g. their job or organization. As has been found with other constructs (e.g. social exchange, justice, commitment, citizenship behavior: Lavelle, Rupp \& Brockner, 2007), so the authors argue that it is relevant to adopt a multi-foci perspective with employee engagement. The same argument was made by Reichers (1985) about commitment to a range of different targets. Consequent researchers confirmed different role related commitments perspective. Saks (2006) published the first research on organizational engagement along with job engagement, suggesting 
that there is a "meaningful difference" (Saks, 2006, p. 600) between these two. In the current study, the authors develop Saks (2006) operationalization further, maintaining that organizational engagement can be explained similar to job engagement, however, with an organization-level referent. Thus, the current research focuses on both job and organizational engagement (herewith called employee engagement) in this study.

\subsection{Hope and employee engagement}

Employees who are high in hope have will and feasible ways to accomplish a particular objective (Luthans, Avey \& Patera, 2008). Individuals with personal strengths are greatly engaged in their job and have the ability to regulate their work environment effectively. Although the motivational process of the JD-R model proposes that job resources and personal resources influence job engagement independently or jointly (Bakker \& Demerouti, 2008). Different scholars have examined the relationships between different personal resources including: active coping style, self-efficacy, organizational-based self-esteem, resilience and optimism and job engagement (Xanthopoulou, Bakker, Demerouti \& Schaufeli, 2007). However, the literature review reveals that only three empirical studies found the positive effect of hope on job engagement in the current literature (Karatepe, 2014; Ouweneel et al., 2012).

Although as mentioned above, hope is related to a number of favorable outcomes, e.g., better performance, good health, extra ordinary problem-solving skills, psychological stability, and job engagement (Lopez et al., 2004), no prior research has examined it with employees' organizational engagement.

As an imperative personality characteristic, hope may be associated with OE. Agency thoughts (e.g., positive past experiences) encourage individuals to follow or take the benefit of strategies that will lead to accomplishment of objectives (e.g., promotion in the current organization). Not surprisingly, individuals high in hope have the supernatural capability to search alternatives to obtain their objectives (Avey, Wernsing \& Luthans, 2008). According to Snyder (2002, p. 251), agency thinking "takes on special significance when people encounter impediments. During such blockages, agency helps people to channel the requisite motivation to the best alternative pathway". Therefore, this study maintains that hopeful employees may develop organizational engagement.

Precisely, individuals having higher personal resources (e.g., hope) are vastly engaged in their organization and job as they may control their immediate work environment successfully. In light of this discussion, hope stimulates workers to feel energetic and dedicated and be immersed in their job and organization. On the basis of this discussion, it is hypothesized that 
$\mathrm{H}_{1}$. Hope positively impacts (a) job engagement and (b) organizational engagement.

\subsection{Knowledge sharing behavior}

Knowledge sharing can be described as a transfer or flow of knowledge (Schulz, 2001). It is the process of exchanging, receiving and benefiting from other's experiences and knowledge (Wijk van, Jansen \& Lyles, 2008). It is a collaborative effort with a mutual exchange of knowledge, which results in a joint effort of creating new knowledge (Van den Hooff \& De Ridder, 2004). Organizations encourage knowledge sharing at the employee level, as well as embed it into their systems and structure (Lagerstrom \& Andersson, 2003).

The knowledge management literature reveals that knowledge is something that can and should be shared. It is a resource which is of immense importance. Knowledge sharing can result in increasing an organization's important resources, as in this process, individual knowledge is transformed into organizational knowledge (Van den Hooff \& de Leeuw van Weenen, 2004). Past literature claims that knowledge sharing brings various benefits to organizations, including reduced production costs, increased performance and more innovation at the organizational level (Mesmer-Magnus \& DeChurch, 2009).

\subsection{Employee engagement and KSB}

Employees who are engaged with work and organization are likely to be productive and knowledge sharer in the current organization. Though limited, there is some evidence to support these assertions. For example, Song, Kim, Chai and Bae (2014) study demonstrated that JE boosted job satisfaction. Karatepe (2012) investigation among frontline hotel employees in Cameroon showed that JE fostered career satisfaction. Hakanen and Schaufeli (2012) study also provided evidence regarding the positive impact of JE on life satisfaction. Although there are empirical studies that delineate the impact of JE on employees' attitudinal outcomes such as job, career and life satisfaction, these relationships need further empirical attention.

A few research studies have also shown that job engagement is related to sharing knowledge. For instance, Chen et al., (2011) integrated job-engagement theory with conflict management theory. They conducted their research in two software development companies in China and concluded that task conflict positively lead to engagement which resulted in enhanced knowledge sharing. Tang et al. (2015) found that psychological engagement partially mediated ethical leadership-knowledge management (knowledge sharing and knowledge hiding) relationship in Hong Kong. As knowledge sharing itself is a self-motivated process, employees will be more likely to share their expertise with their colleagues only when they are dedicated to their work and enthusiastic about their organization. However, knowledge sharing is not 
equally and regularly distributed because sharing of knowledge is not an official task. Also, sharing of knowledge develops an organization's ability to develop competencies to build a competitive advantage of an organization (Reid, 2003). Knowledge sharing is a culture of social interaction, where employees share knowledge, skills and competencies. It is an understanding of creating knowledge networks and offering access to information to employees (Hogel, Parboteeah \& Munson, 2003). Moreover, organizational engagement is less studied construct as compared to job engagement (Guest, 2014). The following paragraph explains the brief review of available research on organizational engagement and work outcomes.

Some empirical studies have reported relationships between organizational engagement and work outcomes. For instance, organizational engagement has been found to be positively related to organizational commitment, job satisfaction, organization citizenship behavior, service climate, affective commitment, active learning, initiative, and organizational performance (Juhdi et al., 2013; Saks, 2006) and negatively related to turnover intention (Saks, 2006). On the basis of this literature review this study maintains that individuals who are engaged with their organization will share their knowledge with other organizational members.

Therefore, it is hypothesized that

$\mathrm{H}_{2}$. (a) Job engagement and (b) organizational engagement positively impact knowledge sharing behavior.

\subsection{Innovative work behavior}

Organizations nowadays, are focusing on innovation in order to remain competitive. An organization's innovative capability is one of the most imperative elements determining its performance, success and sustainability (Dess \& Picken, 2000). IWB is defined as "the intentional introduction and application within a role, group or organization of ideas, processes, products or procedures" (West \& Farr, 1990, p. 9). It has been realized that "innovation is power", therefore, the role and significance of organizational innovation is increasing day by day (Khan, Rehman \& Fatima, 2009). It is a complex process which is intended to develop, achieve and adapt to an idea. It is the formation of new and beneficial products or services (Gumusluoglu \& Ilsev, 2009).

To enjoy competitive advantage in the current highly competitive world, organizations must innovate (McAdam \& Keogh, 2004). Mainly, employee innovative behaviors are important in the dynamic situation (Yuan \& Woodman, 2010). Additionally, management need innovative individuals to maintain their competitive positions in the market (Zhou \& Shalley, 2008). 


\subsection{Knowledge sharing and innovative work behavior}

Innovative work behavior is important for work-role, group and organizational performance (De Jong \& den Hartog, 2010). The scope of IWB includes innovations to products, services and/or work processes. While sharing knowledge employees do not simply pass on information rather they also intricate and 'translate' it into a way that is understandable to others (Hansen, Mors \& Lovas, 2005). In this process, the capacity to innovate of knowledge sharers is enhanced.

Radaelli et al. (2014) found that workers who share knowledge also engage more in creating, promoting and implementing innovations. They found a direct, unmediated link between two behaviors. Kim and Park (2015) found knowledge sharing directly affected innovation. Yu, Yu and Yu (2013) found through hierarchical linear modeling (HLM) that there is a positive relation between KSB and IWB. Therefore, it is hypothesized that

$\mathrm{H}_{3}$ : Knowledge sharing behavior positively impacts innovative work behavior.

Finally, on the basis of all discussion and available empirical results following hypothesis is also proposed.

$\mathrm{H}_{4}$ : Hope has an impact on IWB through JE, OE and KSB such that (a)JE KSB act as mediators simultaneously and (b) OE and KSB act as mediators simultaneously.

\subsection{Theoretical framework}

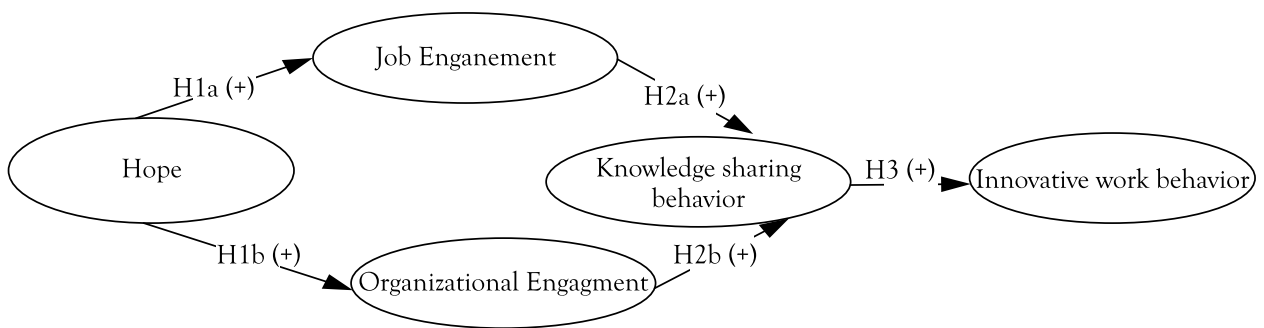

Figure 1: Theoretical Framework of the Study

\section{Methodology}

\subsection{Type of research}

This study is descriptive, correlational, cross-sectional, fundamental and quantitative research. This study applies a hypothetico-deductive method. The methodology adopted for this paper is mono-method quantitative research as it is more appropriate for answering the research questions posed. This paper uses quantitative survey for collecting data. Though this study recognizes the strengths of longitudinal research, 
a cross-sectional data collection method was employed. This choice was governed by the time, data access and resource constraints.

\subsection{Sample and procedure}

The current research examines the path starting from personal resource, i.e., hope leading to engagement and KSB and resulting in increased IWB. This research aims to test the relationship and sequence of occurrence of the research variables. The research was conducted using a Homogeneous sampling, which is a purposive sampling technique. It is aimed to achieve a homogeneous sample; i.e., a sample whose units share similar characteristics (e.g., a group of people that are similar in terms of occupation). It is one of the most cost-effective and time-effective sampling methods available. Researchers suggest that employees' jobs in the ICT industry involve KSB and IWB due to continuous environmental changes (Fatima, Imran, Shahab \& Zulfiqar, 2015). Thus, the ICT industry was purposively chosen for this research utilizing a purposive sample of 354 employees of ICT sector operating in the twin cities of Pakistan i.e., Rawalpindi and Islamabad. These two cities were chosen because Rawalpindi and Islamabad are the hub of the ICT industry in the country. Also Pakistan Software Export Board (PSEB) ${ }^{3}$ established first Software Technology Park in 1999 in Islamabad. The importance of these cities manifest from the fact that these two cities have $40 \%$ share of the total business of ICT in Pakistan. This is because a number of multinational companies have established their offices here (Software Technology Parks," n.d. PSEB, 2017; Pro Pakistani, 2017).

Like other developing countries, collecting data is tough in Pakistan (Taskeen, Shehzadi, Khan \& Saleem, 2014). There is a lack of appreciation of the importance of data collection (Elahi, 2008). Pakistanis are not familiar to fill in instruments and return them. Not properly filling the questionnaire and the lack of respondent support typically obscure the practice of collecting data in Pakistan (Taskeen et al., 2014). Accordingly, when gathering primary data in Pakistan, non-probability sampling techniques (such as convenience and purposive) is preferably used and assumed to be the most appropriate form of sampling (Attiq, Rasool \& Iqbal, 2017). Consequently, this research used a purposive sample. Convenience and purposive samples are very common in social science studies and are extensively utilized in organizational studies since they help save time, effort and money (Bryman, 2012).

Both subjective and objective criteria were used to confirm sample adequacy. Subjectively, the sample size of this research is greater than 200. Moreover, objectively

3 Software Technology parks.(n.d.). Retrieved from http://www.pseb.org.pk/pseb-programs/it-parks 4 Pro Pakistani (2017). The 3rd ICT awards. [Press release]. Retrieved from https://propakistani. pk/2017/04/12/rcci-organiz-es-3rd-ict-awards/ 
the threshold $(5: 1)$ defined by the extensively used ratio for maximum likelihood estimation, i.e., $\mathrm{N}: \mathrm{q}$ (where $\mathrm{N}=$ number of cases and $\mathrm{q}=$ number of parameters), the sample size of the present study satisfied the assumption as it proved to be 354:39 revealing approximately 9:1 (Kline, 2011). Here 354 denote the number of cases while 39 denote the number of parameters respectively.

The sample consisted of $65 \%$ males and $35 \%$ females. The majority of them belonged to the age ranging between 25-45 (82\%); with experience in their current organization between 9 months to 10 years (75\%); and holding a masters' degree (48\%). Hypotheses were tested using a structural equation modelling (SEM) technique as it appears to be the most appropriate method to test the whole model simultaneously. M-Plus 8 software was employed using maximum likelihood estimation.

\subsection{Instruments}

Measurement items of the concepts used in this research have been adapted from literature. Four items were used to measure hope (Snyder et al., 1996). One item was deleted at confirmatory factor analysis (CFA) stage because its standardized loading was below 0.40 at $\mathrm{p}<0.05$ (Leech, Barrett \& Morgan, 2005). Job engagement was tapped using the Utrecht Work Engagement Scale (UWES; Schaufeli et al., 2002). Using Saks (2006) engagement instrument, four items were used to measure organizational engagement. Two items were deleted from organizational engagement scale during CFA due to low item loading values. Five item scale of Bock, Zmud, Kim \& Lee (2005) was used for KSB. Finally, nine-item scale for individual innovative behavior (Scott \& Bruce, 1994) was also used. All responses were taken on a 5 point Likert type scale.

\subsection{Data analysis}

This research employed CFA and SEM through MPlus version 7. Specifically, in the current study a two-step approach containing CFA and SEM was employed (Anderson \& Gerbing, 1988). In the first step, the measurement model was assessed in terms of convergent and discriminant validity (Anderson \& Gerbing, 1988). The second step was associated with examining the structural model.

The fully and partially mediated models were compared based on the $\chi^{2}$ difference test. Specifically, the partially mediated model consisted of the direct effect of Hope on IWB as well as the indirect effect of hope on IWB through work and organizational engagement and KSB. The fully mediated model included the indirect effects of hope on IWB through work and organizational engagement and KSB. Having no significant difference in fit suggests that the partially mediated model does not improve fit. Moreover, prior studies have suggested that bootstrapping is an appropriate 
technique for testing the indirect effects, especially in studies considering multiple mediators (Preacher \& Hayes, 2008). Therefore, this study has also used bootstrapping procedures to test indirect effects.

\section{Analysis and Results}

\subsection{Correlation analysis and discriminant validity}

Correlation analysis is carried out to examine relationships among constructs. The results show all the variables are positively and significantly related. Mean value of variables ranges from 3.52 to 3.69 and standard deviation ranges from 0.72 to 0.87 . Minimum value was 1 , while maximum value was 5 . Moreover, the square root of aver-

Table 1: Descriptive Statistics and Correlation Analysis of Study Variables

\begin{tabular}{|c|c|c|c|c|c|c|c|c|c|}
\hline Variables & MEAN & S.D. & Min & Max & JE & OE & HOPE & IWB & KSB \\
\hline JE & 3.55 & 0.72 & 1 & 5 & 1 & & & & \\
\hline OE & 3.57 & 0.87 & 1 & 5 & $.676^{* *}$ & 1 & & & \\
\hline Hope & 3.69 & 0.81 & 1 & 5 & $.621^{* *}$ & $.504^{* *}$ & 1 & & \\
\hline IWB & 3.52 & 0.74 & 1 & 5 & $.703^{* *}$ & $.548^{* *}$ & $.467^{* *}$ & 1 & \\
\hline KSB & 3.67 & 0.77 & 1 & 5 & $.701^{* *}$ & $.556^{* *}$ & $.521^{* *}$ & $.593^{* *}$ & 1 \\
\hline$(\sqrt{\text { AVE }})$ & & & & & 0.768 & 0.660 & 0.705 & 0.616 & 0.766 \\
\hline
\end{tabular}

**. Correlation is significant at the 0.01 level (2-tailed).

$\mathrm{JE}=\mathrm{Job}$ engagement, $\mathrm{OE}=$ Organizational engagement, $\mathrm{IWB}=$ Innovative work behavior, $\mathrm{KSB}=$ Knowledge sharing behavior

age variance extracted for all the variables was greater than corresponding correlation coefficient values with other variables i.e., providing discriminant validity evidence.

For normality, skewness and kurtosis test results are in an acceptable range.

\subsection{CMV with Harman's single factor test}

To check common method variance and systematic measurement error in survey data, Harman's single-factor test was also applied to establish common method vari-

Table 2: Results of CMV Analysis (Total Variance Explained)

\begin{tabular}{|c|c|c|c|c|c|c|}
\hline \multirow{2}{*}{ Component } & \multicolumn{3}{|c|}{ Initial Eigenvalues } & \multicolumn{3}{c|}{ Extraction Sums of Squared Loadings } \\
\cline { 2 - 7 } & Total & \% of Variance & $\begin{array}{c}\text { Cumulative } \\
\%\end{array}$ & Total & \% of Variance & $\begin{array}{c}\text { Cumulative } \\
\%\end{array}$ \\
\hline 1 & 13.508 & 34.634 & 34.634 & 13.508 & 34.634 & 34.636 \\
\hline & & & \multicolumn{3}{c|}{ Total Variance 56.74} \\
\hline
\end{tabular}


ance (CMV). The results (Table 2) below displays that variance of 1st factor exhibits $34.64 \%$ of total variance which was lesser than standard tolerance limit i.e. $49 \%$. It showed no issue regarding CMV in survey data.

\subsection{Multicollinearity}

Table 3: Multicollinearity Analysis

\begin{tabular}{|c|c|c|c|c|}
\hline \multicolumn{5}{|c|}{ Collinearity Statistics } \\
\hline & \multicolumn{2}{|c|}{ Tolerance } & \multicolumn{2}{|c|}{ Variance Inflation Factor } \\
\hline \multicolumn{5}{|c|}{ CASE 1 (Hope $\rightarrow$ JE and Hope $\rightarrow$ OE) } \\
\hline IDV & $\mathrm{JE}$ & $\mathrm{OE}$ & $\mathrm{JE}$ & OE \\
\hline HOPE & 1.000 & 1.000 & 1.000 & 1.000 \\
\hline \multicolumn{5}{|c|}{ CASE 2 (JE,OE $\rightarrow$ KSB) } \\
\hline IDV & \multicolumn{2}{|c|}{$\mathrm{KSB}$} & \multicolumn{2}{|c|}{ KSB } \\
\hline $\mathrm{JE}$ & \multicolumn{2}{|c|}{0.543} & \multicolumn{2}{|c|}{1.843} \\
\hline $\mathrm{OE}$ & \multicolumn{2}{|c|}{0.543} & \multicolumn{2}{|c|}{1.843} \\
\hline \multicolumn{5}{|c|}{ CASE 3 (KSB $\rightarrow$ IWB) } \\
\hline IDV & \multicolumn{2}{|c|}{ IWB } & \multicolumn{2}{|c|}{ IWB } \\
\hline KSB & \multicolumn{2}{|c|}{1.000} & \multicolumn{2}{|c|}{1.000} \\
\hline
\end{tabular}

$\mathrm{IDV}=$ Independent variable, $\mathrm{JE}=$ Job engagement, $\mathrm{OE}=$ Organizational engagement, $\mathrm{IWB}=$ Innovative work behavior, $\mathrm{KSB}=$ Knowledge sharing behavior

For multicollinearity, variance inflation factor (VIF) and tolerance tests were employed on all endogenous variables separately. The results represented no issue of multicollinearity as VIF values are less than 10 and tolerance values are above 0.10 (see Table 3) recommended by O'brien (2007).

\subsection{Reliability}

To check reliability of variables reliability analyses were conducted using two methods i.e., Cronbach's alpha and composite reliability. Coefficient alpha is mostly used for reliability assessment (Hair, Black, Babin \& Anderson, 2010). However, there is an issue with this measure that with the increase in the number of the items will increase the value of coefficient alpha (Hair et al., 2010). To avoid this issue, reliability measures resulting from CFA known as the composite reliability was advised (Hair et al., 2010). Accordingly, the reliability of the constructs was assessed using both Cronbach's alpha and the composite reliability.

Composite reliability is calculated as follows: 
Table 4: Construct Reliability

\begin{tabular}{|c|c|c|}
\hline Constructs & Composite Reliability & Alpha \\
\hline JE & 0.980 & 0.896 \\
\hline OE & 0.808 & 0.809 \\
\hline Hope & 0.747 & 0.723 \\
\hline IWB & 0.943 & 0.854 \\
\hline KS & 0.890 & 0.801 \\
\hline
\end{tabular}

$\mathrm{JE}=$ Job engagement, $\mathrm{OE}=$ Organizational engagement, $\mathrm{IWB}=$ Innovative work behavior, $\mathrm{KSB}=$ Knowledge sharing behavior

$$
\text { Composite } \text { Re liability }=\frac{(\Sigma \text { Standardized Loading })^{2}}{(\Sigma \text { Standardized Loading }) 2+\Sigma \varepsilon j}
$$

In the above equation the measurement error of each indicator can be calculated using following formula.

\section{1- (Standardized loading) $)^{2}$}

\subsection{Testing of measurement model}

Job engagement is a higher order construct, therefore, the researcher compared the second order construct with a one-factor model of job engagement. In a one factor model all items of job engagement were grouped to form one grand job engagement factor. Likewise, in second CFA JE was treated as a second-order model. In this model all items were subject to load on their respective factor (i.e., vigor, absorption and dedication) and all factor were to load on the second order JE construct.

The results reveal that the fit of the second order JE provide better fit than one factor JE. To further assess model fitness, a chi-square difference test was also performed. The test showed a significant chi-square change indicating that the two models are significantly different, and supporting JE as a second order construct. $\left[\chi^{2}\right.$ difference $=31.256, \mathrm{df}=3, \mathrm{p}<0.001]$.

CFA was then performed to confirm the loading and significance of all the items of the study. All the items had significant factor loadings greater than 0.50 and thus were retained except few items. The results show the evidence of convergent validity as all loadings are highly loaded on their own constructs. Goodness of model fit also presented satisfactory results of indices, i.e. $\chi^{2}=916.812, \mathrm{Df}=566, \mathrm{CMIN} / \mathrm{Df}=$ $1.619^{* * *} ; \mathrm{CFI}=0.896 ; \mathrm{RMSEA}=0.059, \mathrm{SRMR}=0.064$. 
Table 5: Verification of Convergent Validity

\begin{tabular}{|c|c|c|c|}
\hline & Standardized Estimate $(\beta)$ & $\mathrm{SE}$ & Two-Tailed p-value \\
\hline \multicolumn{4}{|l|}{ Hope by } \\
\hline HOP1 & \multicolumn{3}{|c|}{ Deleted } \\
\hline HOP2 & 0.770 & 0.048 & 0.000 \\
\hline HOP3 & 0.703 & 0.052 & 0.000 \\
\hline HOP4 & 0.636 & 0.058 & 0.000 \\
\hline \multicolumn{4}{|l|}{ JE by } \\
\hline Vigor & 0.978 & 0.026 & 0.000 \\
\hline Absorption & 0.997 & 0.025 & 0.000 \\
\hline Dedication & 0.902 & 0.028 & 0.000 \\
\hline \multicolumn{4}{|l|}{ Vigor by } \\
\hline JE1 & 0.614 & 0.053 & 0.000 \\
\hline JE2 & 0.620 & 0.052 & 0.000 \\
\hline JE3 & 0.572 & 0.055 & 0.000 \\
\hline JE4 & 0.613 & 0.053 & 0.000 \\
\hline JE5 & 0.627 & 0.051 & 0.000 \\
\hline JE6 & \multicolumn{3}{|c|}{ Deleted } \\
\hline \multicolumn{4}{|l|}{ Absorption by } \\
\hline JE7 & 0.656 & 0.046 & 0.000 \\
\hline JE8 & 0.537 & 0.057 & 0.000 \\
\hline JE9 & 0.622 & 0.050 & 0.000 \\
\hline JE10 & 0.613 & 0.052 & 0.000 \\
\hline JE11 & 0.593 & 0.054 & 0.000 \\
\hline JE 12 & \multicolumn{3}{|c|}{ Deleted } \\
\hline \multicolumn{4}{|l|}{ Dedication by } \\
\hline JE13 & 0.587 & 0.055 & 0.000 \\
\hline JE14 & 0.652 & 0.048 & 0.000 \\
\hline $\mathrm{JE} 15$ & 0.774 & 0.037 & 0.000 \\
\hline JE16 & 0.657 & 0.049 & 0.000 \\
\hline JE17 & 0.704 & 0.044 & 0.000 \\
\hline \multicolumn{4}{|l|}{ OE by } \\
\hline OE1 & 0.689 & 0.052 & 0.000 \\
\hline OE2 & 0.713 & 0.048 & 0.000 \\
\hline
\end{tabular}




\begin{tabular}{|c|c|c|c|}
\hline OE3 & 0.751 & 0.045 & 0.000 \\
\hline OE4 & 0.519 & 0.064 & 0.000 \\
\hline OE 5 & \multicolumn{3}{|c|}{ Deleted } \\
\hline OE 6 & \multicolumn{3}{|c|}{ Deleted } \\
\hline \multicolumn{4}{|l|}{ IWB by } \\
\hline IWB1 & 0.648 & 0.052 & 0.000 \\
\hline IWB2 & 0.629 & 0.051 & 0.000 \\
\hline IWB3 & 0.711 & 0.044 & 0.000 \\
\hline IWB4 & 0.736 & 0.043 & 0.000 \\
\hline IWB5 & 0.647 & 0.050 & 0.000 \\
\hline IWB6 & 0.575 & 0.056 & 0.000 \\
\hline IWB7 & 0.513 & 0.061 & 0.000 \\
\hline IWB8 & 0.535 & 0.060 & 0.000 \\
\hline IWB9 & 0.546 & 0.058 & 0.000 \\
\hline \multicolumn{4}{|l|}{ KS BY } \\
\hline KSE & 0.979 & 0.088 & 0.000 \\
\hline KSI & 0.894 & 0.051 & 0.000 \\
\hline \multicolumn{4}{|l|}{ KSE by } \\
\hline KS1 & 0.944 & 0.073 & 0.000 \\
\hline KS2 & 0.894 & 0.064 & 0.000 \\
\hline \multicolumn{4}{|l|}{ KSI by } \\
\hline KS3 & 0.710 & 0.051 & 0.000 \\
\hline KS4 & 0.621 & 0.056 & 0.000 \\
\hline KS5 & 0.754 & 0.046 & 0.000 \\
\hline
\end{tabular}

$\mathrm{SE}=$ Standard error, $\mathrm{JE}=$ Job engagement, $\mathrm{OE}=$ Organizational engagement, IWB=Innovative work behavior, $\mathrm{KSB}=$ Knowledge sharing behavior

\subsection{Structural model testing}

Structural model comprised of one exogenous variable and 4 endogenous variables. Model fit presented satisfactory results of indices, i.e. $\chi^{2}=1024.292$, Df $=571$; $\mathrm{CMIN} / \mathrm{Df}=1.79^{* * *} ; \mathrm{CFI}=0.830 ; \mathrm{RMSEA}=0.065, \mathrm{SRMR}=0.079$.

\subsubsection{Hypotheses testing - baseline model}

In structural model analysis, according to hypothesis 1 (hope $\rightarrow \mathrm{JE}, \mathrm{OE}$ ), the value of standardized regression $\left(\mathrm{H}_{1 \mathrm{a}}: \beta=0.746, \mathrm{p}<0.001 ; \mathrm{H}_{1 \mathrm{~b}}: \beta=0.498, \mathrm{p}<0.001\right)$ 
Table 6: Assessing Structural Model Validity of Baseline Model

\begin{tabular}{|c|c|}
\hline HYPOTHESES & $\beta$ \\
\hline $\mathrm{H}_{1 \mathrm{a}}:$ Hope will be positively related to job engagement. (Supported) & $0.746^{* * *}$ \\
\hline $\mathrm{H}_{1 \mathrm{~b}}$ : Hope will be positively related to organizational engagement. (Supported) & $0.498^{* * *}$ \\
\hline $\begin{array}{l}\mathrm{H}_{2 \mathrm{a}}: \text { Job engagement will be positively related to knowledge sharing behavior. } \\
\text { (Supported) }\end{array}$ & $0.669 * * *$ \\
\hline $\begin{array}{c}\mathrm{H}_{2 \mathrm{~b}} \text { : Organizational engagement will be positively related to knowledge sharing } \\
\text { behavior. (Supported) }\end{array}$ & $0.222^{*}$ \\
\hline $\begin{array}{l}\mathrm{H}_{3}: \text { Knowledge sharing will be positively linked to innovative work behavior. (Sup- } \\
\text { ported) }\end{array}$ & $0.399^{* * *}$ \\
\hline
\end{tabular}

${ }^{*} \mathrm{p}<0.10,{ }^{* * *} \mathrm{p}<0.001$

indicated a significant positive and strong relationship between hope and job and organizational engagement. Also, there was a significant positive relationship between job engagement and $\mathrm{KSB}\left(\mathrm{H}_{2 \mathrm{a}}: \beta=0.669, \mathrm{p}<0.001\right)$ and organizational engagement and $\mathrm{KSB}\left(\mathrm{H}_{2 \mathrm{~b}}: \beta=0.222, \mathrm{p}<0.10\right)$, thus hypothesis 2 is also accepted. Similarly, sig-

Table 7: $\mathrm{R}^{2}$ Values for the Model

\begin{tabular}{|c|c|}
\hline Latent Variables & $\mathrm{R}^{2}$ \\
\hline JE & 0.562 \\
\hline OE & 0.254 \\
\hline IWB & 0.228 \\
\hline KS & 0.587 \\
\hline
\end{tabular}

$\mathrm{JE}=$ Job engagement, $\mathrm{OE}=$ Organizational engagement, $\mathrm{IWB}=$ Innovative work behavior, $\mathrm{KSB}=$ Knowledge sharing behavior

nificant relation exists between KSB and IWB $\left(\mathrm{H}_{3}: \beta=0.399, \mathrm{p}<0.001\right)$ supporting hypothesis 3 .

\subsubsection{Co-Efficient of determination $R^{2}$}

Following table represents the values of $\mathrm{R}^{2}$ for all the endogenous variables of study. All the values are greater than 0.10 .

\subsubsection{Hypotheses testing - mediation analysis}

The current study examines that the constructs could function as a casual chain, a model referred to as serial mediation (Hayes, 2012). It is referred to as "a causal chain linking the mediators, with a specified direction of causal flow" (Hayes, 2012, 
p. 14). That means, hope could increase job and organizational engagement, job and organizational engagement could influence their $\mathrm{KSB}$, and this behavior could predict IWB. Serial mediation is important to explore as the differential impact of specific constructs could be symptomatic of an underlying (and untested) casual chain.

The fully mediated or hypothesized model is compared with the alternative partially mediated model. This nested model approach is consistent with the recommendations provided by researchers for testing the mediating effects based on the comparison of alternative models (James, Mulaik \& Brett, 2006). This method of testing mediation is consistent with earlier researches that have tested mediation hypotheses using SEM (e.g. Rich et al., 2010). In the alternative partial mediating model, the researcher included these relationships along with direct effect of hope on IWB. Partially mediated model was less fit as compared to fully mediated research model $\left(\chi^{2}=1023.271, \mathrm{df}=570 ; \mathrm{CMIN} / \mathrm{Df}=1.79^{* * *} ; \mathrm{CFI}=0.818 ; \mathrm{RMSEA}=0.069, \mathrm{SRMR}\right.$

Table 8: Results of Model Comparison.f

\begin{tabular}{|c|c|c|c|c|c|}
\hline Models & $\chi^{2}$ & Df & $\Delta \chi^{2}$ & $\Delta$ df & Model comparison \\
\hline 1. Fully mediated model & 1024.292 & 571 & & & \\
\hline $\begin{array}{c}\text { 2. Partially mediated } \\
\text { model }\end{array}$ & 1023.271 & 570 & 1.021 & 1 & 1 and 2 \\
\hline
\end{tabular}

$=0.085)$. Fully mediated model was compared with partially model based on the $\chi^{2}$ difference test $(\mathrm{p}<0.01)$ (Chen et al., 2005). The $\chi^{2}$ difference test for the fully $\left(\chi^{2}=\right.$ 1024.292, $\mathrm{df}=571)$ and partially $\left(\chi^{2}=1023.271, \mathrm{df}=570\right)$ mediated models showed a non-significant difference in fit $\left(\Delta \chi^{2}=1.021, \Delta \mathrm{df}=1\right)$. The fully mediated model appeared to provide better fit to the data than did the partially mediated model. The fully mediated model fit the data adequately based on a number of fit statistics: $\left(\chi^{2}\right.$ $=1024.292, \mathrm{Df}=571 ; \mathrm{CMIN} / \mathrm{Df}=1.79^{* * *} ; \mathrm{CFI}=0.830 ; \mathrm{RMSEA}=0.065, \mathrm{SRMR}=$ $0.079)$.

Thus, the hypothesized mediated model was superior to the alternative partial mediated model as it was more parsimonious and fit the data well.

Moreover, table 8 shows that the specific indirect effect through JE is significant but $\mathrm{OE}$ is not. Thus, $\mathrm{H}_{4 \mathrm{a}}$ is supported and $\mathrm{H}_{4 \mathrm{~b}}$ is not.

To further assess the significance of the mediation, bootstrapping procedures were used (Preacher \& Hayes, 2008). As also mentioned earlier, it is a popular method of testing the indirect effect in the presence of multiple mediators (Shrout $\&$ Bolger, 2002). The bootstrapping procedures in SEM are widely used while performing sequential or serial mediation (Attiq et al., 2017). The advantage of using the 
Table 9: Effects from HOPE to IWB

\begin{tabular}{|c|c|c|c|c|c|}
\hline & $\beta$ & SE & P-Value & $\begin{array}{c}\text { Lower confi- } \\
\text { dence interval } \\
(\text { at 95\%) }\end{array}$ & $\begin{array}{c}\text { Upper confi- } \\
\text { dence interval } \\
\text { (at 95\%) }\end{array}$ \\
\hline Total effect & 0.243 & 0.061 & 0.000 & 0.143 & 0.343 \\
\hline Total Indirect effect & 0.243 & 0.061 & 0.000 & 0.143 & 0.343 \\
\hline $\begin{array}{c}\text { Specific Indirect effect } \\
(\mathrm{H} \rightarrow \mathrm{JE} \rightarrow \mathrm{KS} \rightarrow \mathrm{IWB})\end{array}$ & 0.199 & 0.053 & 0.000 & 0.112 & 0.286 \\
\hline $\begin{array}{c}\text { Specific Indirect effect } \\
(\mathrm{H} \rightarrow \mathrm{OE} \rightarrow \mathrm{KS} \rightarrow \mathrm{IWB})\end{array}$ & 0.044 & 0.027 & 0.105 & -0.001 & 0.089 \\
\hline
\end{tabular}

$\mathrm{SE}=$ Standard error, $\mathrm{H}=\mathrm{Hope}, \mathrm{JE}=\mathrm{Job}$ engagement, $\mathrm{OE}=$ Organizational engagement, IWB=Innovative work behavior, $\mathrm{KSB}=$ Knowledge sharing behavior

bootstrapping approach is that it makes no assumption about the distribution of the standard error associated with the indirect effect and provides confidence intervals for the estimate. The significance of the indirect effect using bootstrapping is established by determining whether zero is contained within the $95 \%$ confidence interval (thus indicating the lack of significance).

The total and total indirect effects of hope on IWB were significant. Moreover, the results presented in the last two columns of the above table were based on 5000 bootstrapped samples using bias-corrected and accelerated $95 \%$ confidence intervals following the propositions of Preacher and Hayes's (2008) and showed that the indirect effects through job engagement and KSB are indeed significantly different from zero at $\mathrm{p}<.05$ (two tailed). However, the results also show that the indirect effects

Table 10(A): The effects from HOPE to KS

\begin{tabular}{|c|c|c|c|c|c|}
\hline & $\beta$ & SE & P-Value & $\begin{array}{c}\text { Lower confi- } \\
\text { dence interval } \\
\text { (at 95\%) }\end{array}$ & $\begin{array}{c}\text { Upper confi- } \\
\text { dence interval } \\
\text { (at 95\%) }\end{array}$ \\
\hline Total effect & 0.609 & 0.084 & 0.000 & 0.472 & 0.747 \\
\hline Total Indirect effect & 0.609 & 0.084 & 0.000 & 0.472 & 0.747 \\
\hline $\begin{array}{c}\text { Specific Indirect effect } \\
(\mathrm{H} \rightarrow \mathrm{JE} \rightarrow \mathrm{KS})\end{array}$ & 0.499 & 0.086 & 0.000 & 0.358 & 0.640 \\
\hline $\begin{array}{c}\text { Specific Indirect effect } \\
(\mathrm{H} \rightarrow \mathrm{OE} \rightarrow \mathrm{KS})\end{array}$ & 0.111 & 0.063 & 0.080 & 0.007 & 0.214 \\
\hline
\end{tabular}

$\mathrm{SE}=$ Standard error, $\mathrm{H}=$ Hope, $\mathrm{JE}=\mathrm{Job}$ engagement, $\mathrm{OE}=$ Organizational engagement, IWB=Innovative work behavior, $\mathrm{KSB}=$ Knowledge sharing behavior 
Table 10(B): Effects from JE to IWB

\begin{tabular}{|c|c|c|c|c|c|}
\hline & $\beta$ & SE & P-Value & $\begin{array}{c}\text { Lower confi- } \\
\text { dence interval } \\
\text { (at 95\%) }\end{array}$ & $\begin{array}{c}\text { Upper confi- } \\
\text { dence interval } \\
\text { (at 95\%) }\end{array}$ \\
\hline Total effect & 0.267 & 0.063 & 0.000 & 0.163 & 0.371 \\
\hline Total Indirect effect & 0.267 & 0.063 & 0.000 & 0.163 & 0.371 \\
\hline $\begin{array}{c}\text { Specific Indirect effect } \\
\text { (JE } \rightarrow \text { KS } \rightarrow \text { IWB })\end{array}$ & 0.267 & 0.063 & 0.000 & 0.167 & 0.371 \\
\hline
\end{tabular}

$\mathrm{SE}=\mathrm{Standard}$ error, $\mathrm{JE}=\mathrm{Job}$ engagement, $\mathrm{IWB}=$ Innovative work behavior, $\mathrm{KSB}=$ Knowledge sharing behavior

Table 10(C): Effects from OE to IWB

\begin{tabular}{|c|c|c|c|c|c|}
\hline & $\beta$ & SE & P-Value & $\begin{array}{c}\text { Lower confi- } \\
\text { dence interval } \\
\text { (at 95\%) }\end{array}$ & $\begin{array}{c}\text { Upper confi- } \\
\text { dence interval } \\
\text { (at 95\%) }\end{array}$ \\
\hline Total effect & 0.089 & 0.051 & 0.082 & 0.005 & 0.172 \\
\hline Total Indirect effect & 0.089 & 0.051 & 0.082 & 0.005 & 0.172 \\
\hline $\begin{array}{c}\text { Specific Indirect effect } \\
(\mathrm{OE} \rightarrow \mathrm{KS} \rightarrow \mathrm{IWB})\end{array}$ & 0.089 & 0.051 & 0.082 & 0.005 & 0.172 \\
\hline
\end{tabular}

$\mathrm{SE}=$ Standard error, $\mathrm{OE}=$ Organizational engagement, $\mathrm{KSB}=$ Knowledge sharing behavior, IW $\mathrm{B}=$ Innovative work behavior

through organizational engagement and KSB are not significantly different from zero at $\mathrm{p}<.05$ (two tailed). Thus, it can be concluded that the job engagement and KS together fully mediated the relationship between hope and IWB but organizational engagement does not.

\subsubsection{Additional indirect analysis}

Besides examining the Hope-IWB indirect link. Following specific indirect links were also tested. All of which were significant. The results presented in the last two columns of Table 10 (A-C) were based on 5000 bootstrapped samples using bias-corrected and accelerated 95\% confidence intervals (Preacher \& Hayes, 2008) and showed that the indirect effects are indeed significantly different from zero at $\mathrm{p}$ $<0.05$ (two tailed).

\section{Discussion and Conclusion}

This study has endeavored to explore the indirect influence of hope on IWB through job engagement, organizational engagement and KSB theoretically as well as empirically. The results revealed the significant impact of hope on employee 
engagement, i.e. job and organization. The results are consistent with past studies (Karatepe, 2014; Ouweneel et al., 2012). The results also find support for a positive link between hope and organizational engagement. In the nutshell, positive psychological resources result in an engaged workforce. Role of hope in affecting job and organizational engagement, as revealed in the results of current study, has important implications. First, these results validate the commonly held belief that hope has consequences that are beneficial for organizations. Second, it provides a way forward to understand the significance and the need to employ skilled as well as psychologically strong employees to create work and organizational engagement in organizations. Third, an engaged workforce, in itself, could be desirable individual attribute (i.e. JE and $\mathrm{OE}$ ) eagerly sought by organizations at present. Thus, this study provides a focus avenue (i.e. psychologically resourceful and engaged workforce) to decision makers for building a knowledge sharing culture, and subsequently nurturing IWB. Consistent with the results of Chen et al. (2011) and Tang et al. (2015), the analysis verified the relation of job engagement and KSB. Similarly, organizational engagement also positively affects KSB. Reasons for a positive relationship between engagement and knowledge sharing can be ascribed to several factors which may include recognition, involvement of employees, organizational and peer support. Finally, analysis also validated the relation of KSB with IWB which is also consistent with past research (Kim \& Park, 2015; Yu et al., 2013).

One of the interesting contributions of current study is that it explains the ways through which hope leads to IWB through job engagement, organizational engagement and KSB. The results show that the indirect effect of hope on IWB through JE and KS is significant supporting $\mathrm{H}_{4 \mathrm{a}}$. However, the indirect link containing $\mathrm{OE}$ is not, thus, $\mathrm{H}_{4 \mathrm{~b}}$ is not. Upon reflection, this somewhat unanticipated result may be explained by the following logic. Employees with high levels of organizational engagement want to see their firms do well and may be so wrapped up and absorbed with the organization itself that they do not have as strong feelings about their innovative ideas and behaviors. Accordingly, in comparison to individuals with high levels of job engagement, individuals with high levels of organizational engagement may focus their cognitive, affective, and physical energies (Rich et al., 2010) on organizational level factors (e.g., organizational performance) and may feel less obligation to be innovative.

The results exhibit that on one side, hope plays an important role in building JE and subsequently affects KSB which leads towards IWB. On the other side, hope enhances organizational effectiveness. These findings signify the importance of building hope in organizations to achieving its positive consequences. With employees holding hope, make them engage in their job and organization which make knowledge exchange possible, thus creating IWB. Hope and engagement develop a supportive 
work environment in the organization which is beneficial for learning by sharing their knowledge and expertise, especially when an individual faces difficulty or get invloved in the novel task for which a solution is not readily present (Scott \& Bruce, 1994). Hence, similar to the findings of Rhoades and Eisenberger (2002), the worker's involvement in a free and open discussion of ideas, assist in the process of innovation. Additional analyses were also conducted to study other indirect relationships in the model including the impact of hope on knowledge sharing through both forms of engagement was significant. Similarly, impact of job and organizational engagement on IWB via KSB was significant.

\subsection{Implications}

In the present knowledge-based environment, IWB is a need, not a choice, for employees engrossed in reacting to advancing technology, changing economic and organizational structures and policies, overcoming innovative competitors and changing clients' requirements (Dess \& Picken, 2000). Therefore, managers need to nurture and take the benefit of the innovative behaviors of their workers. This research can assist managers and scholars to recognize ways in which these requirements can be met.

The relationship of hope with IWB is conceptualized and tested in Pakistan, a South Asian country, on a sample of 354 Pakistani employees in ICT sector organizations representing the most important industry in terms of GDP, employment and world economy integration. This research is highly relevant to the Asian business environment, thought by many to be at the low end of global competitiveness, especially in light of recent political and terrorism chaos.

Despite these challenges, the data reveals that hope is relatively high (mean $=3.69$ on a five-point Likert type scale, $\mathrm{SD}=0.81$ ). This is a promising finding for human resource management in Pakistani organizations since hope is an intrinsic, motivational force that may be developed in organizational settings (Luthans et al., 2008). Since hope constitutes a goal-directed energy and pathway to achieve goals, Pakistani managers should strive to engage employees in a goal setting, pursuing new horizons and participating in identifying the means to reach important goals.

Organizations should consider the acquisition and retention of employees who are high on hope and engagement. This is an important implication due to the high rate of brain-drain and turnover in this industry. Such employees provide quality services and act as role models among other who are not motivated and engaged in the organization. To acquire employees high on hope, engagement, and KSB, management should take advantage of the questionnaires during the hiring process. Managers who are involved in this process should be trained to utilize these ques- 
tionnaires. Management should organize ongoing training to foster employees' skills, abilities, knowledge, and obtain novel ideas and suggestions about how to improve the work done by employees. It appears that management can take advantage of such training to foster employees' psychological capacities. This involves developing hope in training programs designed for employees by making them practice to develop goals and "stepping" sub-goals, creating realistic pathways, accentuating reaching desired outcomes rather than evading undesirable ones, and involve in contingency planning for overcoming potential hitches.

This is likely to result in employee engagement and positive organizational behaviors because research has shown that training programs are successful in developing psychological resources (Avey et al., 2008). Although management can retain employees who are hopeful and engaged in their work, employees cope with a number of tasks and try to respond. Under these circumstances, they may not handle problems associated with stressful situations successfully. Therefore, such environment requires KSB that enables employees to share each other's experiences. In short, management should acknowledge the need for knowledge sharing culture at work and take actions. Lateral hiring refers to the intentional actions of managers to contact and hire individuals in another company (Amankwah-Amoah, 2015). The above mentioned implications can be useful for controlling such threat that might be done by managers in the ICT industry.

This research provides greater understandings to industry associations, training providers, and research institutions in Pakistan. First, hope being a psychological resource is an emerging personality construct in the current literature. However, empirical research regarding the impact of psychological resources on engagement is sparse (De Waal \& Pienaar, 2013; Karatepe, 2014). As also argued by Xanthopoulou et al. (2007), personal resources play a decisive role in employees' engagement. The finding that psychological resources e.g., hope stimulates engagement is not only congruent with the tenets of the COR theory (Xanthopoulou et al., 2007) but also lends support to limited empirical studies (Nigah, Davis \& Hurrell, 2012). The COR theory contends that the presence of personal resources is likely to make employees experience positive outcomes (Alarcon et al., 2013). Employees high in hope own adequate resources from which to draw.

Therefore, from a practical perspective, ICT sector management in Pakistan attempting to improve innovation may use this information when formulating motivation policies and strategies to increase engagement and hence increase desired behaviors. Therefore, it is a necessity for managers to get an insight into the levels of hope and engagement among the workforce by taking regular assessments that may give a complete view. 
From a theoretical perspective, it provides an understanding of the relationships between hope, employee engagement, and positive organizational behaviors in the ICT sector of Pakistan. This research is among the pioneer studies examining the path of psychological resources contributing to job and organizational engagement leading towards positive organizational behaviors i.e., KSB and IWB.

\subsection{Limitations and future research}

This study is not without limitations. Firstly, data for this study was limited to ICT sector. Within ICT sector data were not gathered from firms involved in manufacturing. Researchers in the future may think using a more representative sample of the population of participants from this sector also to make a comparison and distinguish among different segments. Secondly, the current research did not investigate any socio-demographic variables. Future studies can examine the role of gender, age, religion, and spirituality in the study model. Thirdly, hope was found to influence IWB only indirectly. However, future research may replicate the study and find the possible direct effect of hope on IWB. Fourthly, the path passing through organizational engagement was insignificant, this finding needs further exploration. Lastly, there are other important variables that await testing in hope-positive behavior research including citizenship behaviors and organizational commitment etc.

\section{References}

Abbas, M., \& Raja, U. (2015). Impact of psychological capital on innovative performance and job stress. Canadian Journal of Administrative Sciences/Revue Canadienne des Sciences de l'Administration, 32(2), 128-138.

Alarcon, G. M., Bowling, N. A., \& Khazon, S. (2013). Great expectations: A meta-analytic examination of optimism and hope. Personality and Individual Differences, 54(7), 821-827.

Amankwah-Amoah, J. (2015). An integrative review of the antecedents and consequences of lateral hiring. Journal of Management Development, 34(7), 754-772.

Anderson, J. C., \& Gerbing, D. W. (1988). Structural equation modelling in practice: A review and recommended two-step approach. Psychological Bulletin, 103(3), 411-423.

Attiq, S., Rasool, H., \& Iqbal, S. (2017). The impact of supportive work environment, trust, and self-efficacy on organizational learning and its effectiveness: A stimulus-organism response approach. Business Eु Economic Review, 9(2), 73-100.

Avey, J. B., Wernsing, T. S., \& Luthans, F. (2008). Can positive employees help positive organizational change? Impact of psychological capital and emotions on relevant attitudes and behaviors. Journal of Applied Behavioral Science, 44(1), 48-70. 
Bakker, A. B., \& Demerouti, E. (2008). Towards a model of work engagement. Career Development International, 13(3), 209-223.

Bartram, T., \& Rimmer, M. (2012). Editors' note: Dynamism and diversity in Asian HRM. Asia Pacific Journal of Human Resources, 50(1), 1-5.

Bock, G. W., Zmud, R. W., Kim, Y. G., \& Lee, J. N. (2005). Behavioral intention formation in knowledge sharing: examining the roles of extrinsic motivators, social-psychological forces, and organizational climate. MIS Quarterly, 29(1), 87-111.

Bryman, A. (2012). Social research methods. Oxford: Oxford University Press.

Choi, Y., \& Lee, D. (2014). Psychological capital, big five traits, and employee outcomes. Journal of Managerial Psychology, 29(2), 122-140.

Chen, Z. J., Zhang, X., \& Vogel, D. (2011). Exploring the underlying processes between conflict and knowledge sharing: A work-engagement perspective. Journal of Applied Social Psychology, 41(5), 1005-1033.

Dawkins, S., Martin, A., Scott, J., \& Sanderson, K. (2013). Building on the positives: A psychometric review and critical analysis of the construct of psychological capital. Journal of Occupational and Organizational Psychology, 86(3), 348-370.

De Jong, J., \& Den Hartog, D. (2010). Measuring innovative work behavior. Creativity and Innovation Management, 19(1), 23-36.

De Waal, J. J., \& Pienaar, J. (2013). Towards understanding causality between work engagement and psychological capital. SA Journal of Industrial Psychology, 39(2), 1-10.

Dess, G. G., \& Picken, J. C. (2000). Changing roles: Leadership in the 21st century. Organizational Dynamics, 29(4), 18-33.

Drazin, R., \& Schoonhoven, C. B. (1996). Community, population, and organization effects on innovation: A multilevel perspective. Academy of Management Journal, 39(5), 1065-1083.

Elahi, A. (2008). Challenges of data collection: With special regard to developing countries. In Statistics, knowledge and policy 2007 measuring and fostering the progress of societies, (pp. 297-304). OECD Publications, France.

Fatima, A., Imran, R., Shahab, H., \& Zulfiqar, S. (2015). Knowledge sharing among Pakistani IT professionals: Examining the role of procedural justice, pay satisfaction and organizational commitment. Advanced Science Letters, 21(5), 1189-1192.

Gould-Williams, J. S., Mostafa, A. M. S., \& Bottomley, P. (2013). Public service motivation and employee outcomes in the Egyptian public sector: Testing the mediating effect of person-organization fit. Journal of Public Administration Research and Theory, 25(2), 597-622.

Guest, D. (2014). Employee engagement: A sceptical analysis. Journal of Organizational Effectiveness: People 
and Performance, 1(2), 141-156.

Gumusluoglu, L. \& Ilsev, A. (2009). Transformational leadership, creativity, and organizational innovation. Journal of Business Research, 62(4), 461-473.

Hair, J. F., Black, W. C., Babin, B. J., \& Anderson, R. E. (2010). Multivariate data analysis: A global perspective ( $7^{\text {th }}$ ed.). London: Pearson.

Hakanen, J. J., \& Schaufeli, W. B. (2012). Do burnout and work engagement predict depressive symptoms and life satisfaction? A three-wave seven-year prospective study. Journal of Affective Disorders, 141(2), 415-424.

Hansen, M. T., Mors, M. L., \& Lovas, B. (2005). Knowledge sharing in organizations: Multiple networks, multiple phases. Academy of Management Journal, 48(5), 776-793.

Hayes, J. A. (2012). Process: A versatile computational tool for observed variable mediation, moderation, and conditional process modeling. Retrieved from http://www.afhayes.com/public/process2012.pdf

Hobfoll, S. E. (2001). The influence of culture, community, and the nested-self in the stress process: Advancing conservation of resources theory. Applied Psychology, 50(3), 337-421.

Hogel, M., Parboteeah, K. P. \& Munson, C. L., (2003). Team-level antecedents of individuals' knowledge networks. Decision Sciences, 34(4), 741-770.

James, L. R., Mulaik, S. A. \& Brett, J. M. (2006). A tale of two methods. Organizational Research Methods, 9(2), 233-244.

Juhdi, N., Pawan, F., \& Hansaram, R. M. K. (2013). HR practices and turnover intention: The mediating roles of organizational commitment and organizational engagement in a selected region in Malaysia. The International Journal of Human Resource Management, 24(15), 3002-3019.

Kim, S. J., \& Park, M. (2015). Leadership, knowledge sharing, and creativity: The key factors in nurses' innovative behaviors. Journal of Nursing Administration, 45(12), 615-621.

Kim, W., \& Park, J. (2017). Examining structural relationships between work engagement, organizational procedural justice, knowledge sharing, and innovative work behavior for sustainable organizations. Sustainability, 9(205), 1-16.

Karatepe, O. M. (2012). Perceived organizational support, career satisfaction, and performance outcomes: A study of hotel employees in Cameroon. International Journal of Contemporary Hospitality Management, 24(5), 735-752.

Karatepe, O. M. (2014). Hope, work engagement, and organizationally valued performance outcomes: An empirical study in the hotel industry. Journal of Hospitality Marketing $\mathcal{E}$ Management, 23(6), 678-698.

Khan, R., Rehman, A. U., \& Fatima, A. (2009). Transformational leadership and organizational innovation: Moderated by organizational size. African Journal of Business Management, 3(11), 678-684. 
Kline, R. B. (2011). Principles and practice of structural equation modeling. New York, NY: Guilford.

Lagerstrom, K., \& Andersson, M. (2003). Creating and sharing knowledge within a transnational teamThe development of a global business system. Journal of World Business, 38(2), 84-95.

Lavelle, J. J., Rupp, D. E., \& Brockner, J. (2007). Taking a multifoci approach to the study of justice, social exchange, and citizenship behavior: The target similarity model? Journal of Management, 33(6), 841-866.

Leech, N. L., Barrett, K. C., \& Morgan, G. A. (2005). SPSS for intermediate statistics: Use and interpretation ( $2^{\text {nd }}$ ed.). NJ: Lawrence Erlbaum Associates.

Lopez, S. J., Snyder, C. R., Magyar-Moe, J. L., Edwards, L. M., Pedrotti, J. T., Janowski, K., ... \& Pressgrove, C. (2004). Strategies for accentuating hope. In P. A. Linley \& S. Joseph (Eds.), Positive psychology in practice. (pp. 388-404). Hoboken, NJ: John Wiley.

Luthans, F., \& Youssef, C. M. (2004). Human, social, and now positive psychological capital management: Investing in people for competitive advantage. Organizational Dynamics, 33, 143-160.

Luthans, F., Youssef, C. M., \& Avolio, B. J. (2007). Psychological capital: Developing the human competitive edge. Oxford: Oxford University Press.

Luthans, F., Avey, J. B., \& Patera, J. L. (2008). Experimental analysis of a web-based training intervention to develop positive psychological capital. Academy of Management Learning $\mathcal{E}$ Education, 7(2), 209-221.

Luthans, F., Avolio, B. J., Avey, J. B., \& Norman, S. M. (2007). Positive psychological capital: Measurement and relationship with performance and satisfaction. Personnel Psychology, 60(3), 541-572.

May, D. R., Gilson, R. L., \& Harter, L. M. (2004). The psychological conditions of meaningfulness, safety and availability and the engagement of the human spirit at work. Journal of Occupational and Organizational Psychology, 77(1), 11-37.

McAdam, R., \& Keogh, W. (2004). Transitioning towards creativity and innovation measurement in SMEs. Creativity and Innovation Management, 13(2), 126-139.

Mesmer-Magnus, J. R., \& DeChurch, L. A. (2009). Information sharing and team performance: A meta-analysis. Journal of Applied Psychology, 94(2), 535-546.

Nigah, N., Davis, A. J., \& Hurrell, S. A. (2012). The impact of buddying on psychological capital and work engagement: An empirical study of socialization in the professional services sector. Thunderbird International Business Review, 54(6), 891-905.

Norman, S., Luthans, B., \& Luthans, K. (2005). The proposed contagion effect of hopeful leaders on the resiliency of employees and organizations. Journal of Leadership and Organizational Studies, 12, $55-64$.

O'brien, R. M. (2007). A caution regarding rules of thumb for variance inflation factors. Quality 
EQQuantity, 41(5), 673-690.

Ouweneel, E., Le Blanc, P. M., Schaufeli, W. B., \& van Wijhe, C. I. (2012). Good morning, good day: A diary study on positive emotions, hope, and work engagement. Human Relations, 65(9), 1129-1154.

Peterson, S. J., \& Byron, K. (2008). Exploring the role of hope in job performance: Results from four studies. Journal of Organizational Behavior, 29(6), 785-803.

Preacher, K. J., \& Hayes, A. F. (2008). Asymptotic and resampling strategies for assessing and comparing indirect effects in multiple mediator models. Behavior Research Methods, 40(3), 879-891.

Radaelli, G., Lettieri, E., Mura, M., \& Spiller, N. (2014). Knowledge sharing and innovative work behavior in healthcare: A micro-level investigation of direct and indirect effects. Creativity and Innovation Management, 23(4), 400-414.

Rand, K. L. \& Cheavens, J. S. (2009). Hope theory. In S. J. Lopez (Ed.) Oxford handbook of positive psychology, $2^{\text {nd }}$ ed. (pp. 323 - 333). Oxford, UK: Oxford University Press.

Reichers, A. E. (1985). A review and reconceptualization of organizational commitment. Academy of Management Review, 10(3), 465-476.

Reid, F., (2003). Creating a knowledge sharing culture among diverse business units. Employment Relations Today, 30(3), 43-49.

Rhoades, L., \& Eisenberger, R. (2002). Perceived organizational support: A review of the literature. Journal of Applied Psychology, 87(4), 698-714.

Rich, B. L., Lepine, J. A., \& Crawford, E. R. (2010). Job engagement: Antecedents and effects on job performance. Academy of Management Journal, 53(3), 617-635.

Robinson, D., Perryman, S., \& Hayday, S. (2004). The drivers of employee engagement-Report 408 [White Paper]. London:Institute for Employment Studies.

Saks, A. M. (2006). Antecedents and consequences of employee engagement. Journal of Managerial Psychology, 21(7), 600-619.

Schaufeli, W. B., \& Bakker, A. B. (2003). Utrecht work engagement scale: Preliminary manual. Occupational Health Psychology Unit, Utrecht University, Utrecht.

Schaufeli, W. B., Salanova, M., Gonzales-Roma, V., \& Bakker, A. B. (2002). The measurement of engagement and burnout: A two sample confirmatory factor analytic approach. Journal of Happiness Studies, 3, 71-92.

Schulz, M. (2001). The uncertain relevance of newness: Organizational learning and knowledge flows. Academy of Management Journal, 44(4), 661-681.

Shalley, C. E., \& Gilson, L. L. (2004). What leaders need to know: A review of social and contextual factors that can foster or hinder creativity? The Leadership Quarterly, 15(1), 33-53. 
Scott, S. G., \& Bruce, R. A. (1994). Determinants of innovative behavior: A path model of individual innovation in the workplace. Academy of Management Journal, 37(3), 580-607.

Shrout, P. E., \& Bolger, N. (2002). Mediation in experimental and non-experimental studies: New procedures and recommendations. Psychological Methods, 7, 422-445.

Shuck, B., \& Wollard, K. (2010). Employee engagement and HRD: A seminal review of the foundations. Human Resource Development Review, 9(1), 89-110.

Snyder, C. R. (2002). Hope theory: Rainbows in the mind. Psychological Inquiry, 13(4), 249-275.

Snyder, C. R., Sympson, S. C., Ybasco, F. C., Borders, T. F., Babyak, M. A., \& Higgins, R. L. (1996). Development and validation of the State Hope Scale. Journal of Personality and Social Psychology, 70(2), 321-335.

Snyder, C. R., Irving, L., \& Anderson, J. (1991). Hope and health. In C. R. Snyder \& D. R. Forsyth (Eds.), Handbook of social and clinical psychology: The health perspective. (pp. 285-305). Elmsford, NY: Pergamon.

Song, J. H., Kim, W., Chai, D. S., \& Bae, S. H. (2014). The impact of an innovative school climate on teachers' knowledge creation activities in Korean schools: The mediating role of teachers' knowledge sharing and work engagement. KEDI Journal of Educational Policy, 11(2), 179-203.

Tang, P. M., Bavik, Y. L., Chen, Y. F., \& Tjosvold, D. (2015). Linking ethical leadership to knowledge sharing and knowledge hiding: The mediating role of psychological engagement. International Proceedings of Economics Development and Research, 84, 71-76.

Taskeen, S., Shehzadi, A., Khan, T., \& Saleem, N. (2014). Difficulties faced by novice researchers: A study of universities in Pakistan. International Journal of Art and Literature, 1(1), 1-4.

Towers, P. (2003). The 2003 Towers Perrin Talent report: Working today: Understanding what drives employee engagement. Research Report, Towers Perrin, Stamford, CT.

Truss, K., Soane, E., Edwards, C. Y. L., Wisdom, K., Croll, A., \& Burnett, J. (2006). Working life: Employee attitudes and engagement. Chartered Institute of Personnel and Development.

Tseng, M. L., Lin, Y. H., Lim, M. K., \& Teehankee, B. L. (2015). Using a hybrid method to evaluate service innovation in the hotel industry. Applied Soft Computing, 28, 411-421.

Van den Hooff, B., \& de Leeuw van Weenen, F. (2004). Committed to share: Commitment and CMC use as antecedents of knowledge sharing. Knowledge and Process Management, 11(1), 13-24.

West, M. A., \& Farr, J. L. (1990). Innovation and creativity at work: Psychological and organizational strategies. Chichester: Wiley.

Wijk van, R., Jansen, J. J., \& Lyles, M. A. (2008). Inter- and intra-organizational knowledge transfer: A meta-analytic review and assessment of its antecedents and consequences. Journal of Management Studies, 45(4), 830-853. 
Xanthopoulou, D., Bakker, A. B., Demerouti, E., \& Schaufeli, W. B. (2007). The role of personal resources in the job demands-resources model. International Journal of Stress Management, 14, 121-141.

Xanthopoulou, D., Bakker, A. B., \& Ilies, R. (2012). Everyday working life: Explaining within-person fluctuations in employee well-being. Human Relations, 65(9), 1051-1069.

Yavas, U., Babakus, E., \& Karatepe, O. M. (2013). Does hope moderate the impact of job burnout on frontline bank employees' in-role and extra-role performances? International Journal of Bank Marketing, 31(1), 56-70.

Yu, C., Yu, T. F., \& Yu, C. C. (2013). Knowledge sharing, organizational climate, and innovative behavior: A cross-level analysis of effects. Social Behavior and Personality: An International Journal, 41(1), 143-156.

Yuan, F., \& Woodman, R. W. (2010). Innovative behavior in the workplace: The role of performance and image outcome expectations. Academy of Management Journal, 53(2), 323-342.

Zhou, J., \& Shalley, C. E. (2008). Expanding the scope and impact of organizational creativity research. Handbook of organizational creativity, 28, 125-147. 
